\title{
Disposal, characteristics and impact of thermal power plant effluent along the coast of Jaigad, Ratnagiri, Maharashtra
}

\begin{abstract}
ANKITA S. TEKADE, GIRISH N. KULKARNI AND RAHUL K. SADAWARTE
Author for Corresponding -

ANKITAS. TEKADE

ABSTRACT...... The effluent discharge conspicuously affected the temperature, DO, salinity, $\mathrm{pH}$ of the bay water. It showed comparatively lower dissolved oxygen content and high nutrient content in effluent samples. Significant difference $(\mathrm{P}<0.05)$ was observed between the stations in the dissolved oxygen content and temperature. Samples were collected from three different sampling points at Jaigad coastal waters to study the physico-chemical characteristics. The physical and chemical parameters viz., temperature, $\mathrm{pH}$, salinity, alkalinity, DO, total suspended soilds, total dissolved solids, nitrate, phosphate, silicate and sulphate were studied using various standard analytical techniques. The study reveals that the physical and chemical composition of all the samples collected from the sites mainly depends on seasonal variations and discharge from the power plant.
\end{abstract}

Department of Fisheries

Hydrography, College of

Fisheries, Shirgaon, RATNAGIRI

(M.S.) INDIA

Email: ankicofsn@gmail.com

See end of the article for

Coopted authors'
KEY WORDS....... Effluent, Temperature, Salinity, pH, Dissolved oxygen, Nutrients, Jaigad

HOW TO CITE THIS ARTICLE - Tekade, Ankita S., Kulkarni, Girish N. and Sadawarte, Rahul K. (2017). Disposal, characteristics and impact of thermal power plant effluent along the coast of Jaigad, Ratnagiri, Maharashtra. Asian J. Animal Sci.,12(1): 15-21. DOI : 10.15740/HAS/TAJAS/12.1/15-21.

ARTICLE CHRONICLE - Received : 07.03.2017; Revised : 03.05.2017; Accepted : 17.05.2017 